\title{
Music cognition in early infancy: infants' preferences and long-term memory for Ravel
}

\author{
BEATRIZ ILARI \\ Federal University of Paraná (UFPR), Brazil \\ LINDA POLKA \\ McGill University, Montreal, Canada
}

\begin{abstract}
Listening preferences for two pieces, Prelude and Forlane from Le tombeau de Couperin by Maurice Ravel (1875-1937), were assessed in two experiments conducted with 8-month-old infants, using the Headturn Preference Procedure (HPP). Experiment 1 showed that infants, who have never heard the pieces, could clearly make a distinction between the Prelude and Forlane when the latter are played in multiple (i.e. orchestral) but not single (i.e. piano) timbres. In Experiment 2 infants were exposed repeatedly to one of the two piano pieces over a 10-day period. Concurrent with previous studies, results suggested that babies can recognize a familiar piece after a 2-week delay. Implications for early childhood music education are outlined at the end of the article.
\end{abstract}

Key words

babies, early childhood, education, musical development, perception

\section{Introduction}

The world that surrounds the young infant is rich in sounds. As soon as the hearing apparatus starts to function (i.e. around the third trimester of pregnancy), the unborn child awakens to a variety of sounds both from the womb and from the external environment (Abrams et al., 1998). Still in the womb, the fetus responds to external auditory stimuli through body movement and changes in heartbeat (see Woodward et al., 1992). Shortly following birth, neonates can identify sounds that are meaningful and also vital to their development such as the maternal voice (DeCasper \& Fifer, 1980). From the affective sounds of parental speech to the loving melodies of infant-directed singing, the young baby quickly learns to orient towards sound sources (see Trainor \& Trehub, 1990) and to modulate his or her behavior accordingly to the melodic contours of parental speech (Fernald, 1989; Trainor, Austin, \& Desjardins, 2000) and sung musical selections (Rock, Trainor, \& Addison, 1998). It is clear that both music and language play important roles in early auditory development. 


\section{INTERNATIONAL JOURNAL OF MUSIC EDUCATION 24(1)}

Although music has accompanied the growth of many infants across time and in the many different cultures of the world (for examples see Balakrishnan, 1980; Blacking, 1967; Ilari \& Majlis, 2002; West, 2000), it was only in recent years that the study of music cognition in the early years became more systematic and began to take the infant's perspective (i.e. was no longer based on perceptions and reports of parents and caretakers). The last few decades have seen an increase in research on music perception and cognition in early infancy. With the development and further refinement of measurement tools, researchers have challenged the assumption that infants are passive listeners with limited perceptual and cognitive skills for music. Contrary to the notion of the infant entering the world in a blank slate (John Locke 1690, cited in Berk, 1999), there is now evidence showing infants to be sophisticated listeners who perceive music in many adult-like ways (Schellenberg \& Trehub, 1996; Trehub \& Trainor, 1993). For example, young infants perceive melodic contour (see Ferland \& Mendelson, 1989; Trehub, Bull, \& Thorpe, 1984) and are responsive to different pitch alphabets (Lynch \& Eilers, 1992), consonance and dissonance (Schellenberg \& Trehub, 1996; Trainor \& Heinmiller, 1998; Zentner \& Kagan, 1998), timbre (Michel, 1973; Pick, Gross, Heinrich, Love, \& Palmer, 1994), expectation and form (Krumhansl \& Jusczyk, 1990; Melen \& Wachsmann, 2001), among others. In the first year of life, infants also display some sophisticated musical-perceptual abilities such as grouping mechanisms and auditory stream segregation (Demany, McKenzie, \& Vurpillot, 1977; Trehub \& Thorpe, 1989).

Infant listening preferences with respect to music have also been explored, although not as extensively as infant listening preferences for speech. Some of the preference patterns that infants display for speech are also evident for singing. It should be noted that, in the infant cognition literature, listening preference is measured using varied research paradigms (see Clifton, 2001) involving different measures of infant behavior such as sucking, making a head turn towards a particular object or attending longer to one stimulus than another. Preference patterns can provide a direct index of the infant's processing priorities and can also be used to index specific cognitive abilities such as discrimination, segmentation, and memory or recognition.

In terms of musical preferences, the literature suggests that infants prefer infant-directed singing over adult-directed singing and high-pitched singing over low-pitched singing (Trainor, 1996; Trainor \& Zacharias, 1998). According to Trainor and Heinmiller (1998) and Zentner and Kagan (1998) they also prefer to listen to consonant musical pieces over music filled with dissonances. A preference for the piano over other timbres has also been reported in two studies conducted on fetal musical preferences (Wilkin, 1991, 1995). In these studies, heart deceleration levels were used to show fetal preferences for the piano over other timbres.

Recently, the assessment of infant listening preferences has been used to examine infant long-term memory for music as well as for speech. The psychological literature suggests that infant preferences are influenced by age, exposure time, and stimulus complexity. On that note, Hunter and Ames (1988) proposed a multifactor model of infant preference patterns. According to them, infants start with no preferences for an unknown stimulus. Once they begin to explore and process it, they will prefer this familiar stimulus over a novel one. However, once a stimulus is fully explored and further processing is no longer needed, infants tend to get bored with it. Therefore, their preference shifts from a familiar to a novel stimulus. In other words, as stimulus exposure duration increases, infants move from initially (before exposure) showing no preference to preferring familiarity and then to preferring novelty. With either increasing age or reduced stimulus complexity, infants need less exposure time to shift from familiarity to novelty preference. The amount of delay between an exposure period and a preference test also influences infant preference patterns. Yet the 
shift is in the opposite direction with infants showing novelty preference at short delays and familiarity preference at long delays (Spence, 1996).

Within this general framework, preference measures have been used to assess whether infants recognize a previously heard stimulus. For example, Jusczyk and Hohne (1997) used this paradigm to examine infants' memory for spoken words. In their study, infants were exposed to a recorded story repeatedly over a 10-day period; the story contained key words that occurred repeatedly. Infants were tested following a 2-week interval in which they did not hear the story. Only infants in the exposure group displayed a familiarity preference when presented with familiar words from the story along with novel words with similar stress and phonetic properties that did not occur in the story. Infants in a control group who were not exposed to the story showed no preference. Subsequently, using the same design, Saffran, Loman, and Robertson (2000) showed that young infants could retain information from repeated exposure to a Mozart piano piece over a 2-week delay. Altogether, these studies suggest that infants' abilities to represent music and speech in long-term memory are more sophisticated than previously thought. Recent findings also reveal that the infant's initial long-term representations of speech and music include surface or indexical properties of the exposure stimulus. For example, memory for spoken words is initially talker-specific (Houston \& Jusczyk, 2003), and memory for music is initially timbre- and tempo-specific (Trainor, Wu, \& Tsang, 2004).

Despite the research reviewed above, beliefs in the infant as a poor listener still seem to persist. Musical resources (i.e. musical toys, mobiles, CDs, videotapes, books with cassette tapes) geared towards the infant-young child population, for example, reveal some of these beliefs. Following an ever-growing interest in early musical abilities in response to recent findings regarding the importance of early stimulation on brain development (for a discussion see Abrams et al., 1998; Schoenstein, 2002), these resources have expanded in recent years. A careful examination of these readily available resources reveals an implicit belief in the infant as a limited listener. This is especially true for resources that include music of the classical genre. In a survey of 60 infant-related musical resources (see llari \& JohnsonGreen, 2002), only a handful included pieces of romantic, post-romantic, and contemporary musical works. Most surveyed CDs of classical music included primarily short and simple pieces from the Baroque and Classical periods. Furthermore, the majority of these CDs contained pieces of music that were highly repetitive, with structured forms, clear distinctions between melodies and accompaniments, simple chord progressions and harmonies. Hence the choice of repertoire appears to be grounded on the widespread notion of the infant as a poor listener.

Likewise, research on parental beliefs and/or uses of music with young babies has also revealed a stereotyped view of the infant listener (see Custodero, Britto, \& Brooks-Gunn, 2003; Custodero, Britto, \& Xin, 2002; llari, 2005; Johnson-Green \& Custodero, 2002; Trehub et al., 1997). While most parents in the above-mentioned studies reported singing and/or playing music for their infants, only a few of them selected repertoire other than the traditional folk lullabies, playsongs, and nursery rhymes, or classical lullabies and minuets frequently found in CDs and other music-related resources geared towards young children (for some examples see llari \& Johnson-Green, 2002). Whether motivated by the repertoire found in musical toys, mobiles, and CDs, or by their own beliefs and/or previous experiences as children, many parents, consciously or not, continue to sustain the idea that their infants should be limited to music that is highly repetitive and simple (for a discussion, see Bertsch, 2000). The implicit assumption underlying these choices is that the musical processing abilities of infants are limited to repetitive music with simple intervals, contours, rhythms, timbres, and structured forms. In a recent study, Dalla Bella et al. (2001) comment directly on the inadequacies of certain musical works for young listeners. In 


\section{INTERNATIONAL JOURNAL OF MUSIC EDUCATION 24(1)}

discussing the results of their own study on young children's judgments of happy and sad music, they state:

The music presented was of the classical genre and included excerpts up to 20th century composers (e.g. Ravel). Such material is adequate for adults, but perhaps less so for young children. (p. B9)

Studies that investigate how infants process and encode more complex music, that is, music with extended harmonies, unusual rhythmic patterns, and complex timbres, forms, and melodies are needed to address the issue of processing limitations.

In the present study, we explored how infants respond to music that is a bit more sophisticated than the everyday repertoire that is commonly presented to young babies. Two experiments were set for this purpose. Experiment 1 examined whether infants displayed preferences when listening to the music of Ravel and how timbre affected their listening preferences. This first experiment provided the foundation for Experiment 2, which investigated whether infants could remember a complex piece of music, heard previously, after a 2-week delay. Both experiments were conducted with 8-month-olds because previous studies have shown that at this age infants can remember auditory stimuli in the form of words and music after a 2-week delay (Jusczyk \& Hohne, 1997; Saffran, Loman, \& Robertson, 2000).

\section{Experiment 1}

An implicit assumption in early childhood music education is that simple music provides an appropriate match with infant music perception and processing abilities. Yet, as mentioned previously, to date, only a very small number of studies have focused on infants' preferences of music that is a bit more complex than the usual lullabies and playsongs. In Experiment 1, we examined infants' listening preferences for two contrasting pieces from Ravel's Le tombeau de Couperin (Prelude and Forlane) when presented in a single timbre condition (piano) and in a multi-timbre condition (orchestra). The purpose of Experiment 1 was twofold. First, to design Experiment 2 in which we examined infant long-term memory for Ravel, it was necessary to establish whether infants would display a listening preference for one of the two pieces prior to any exposure to this music. If infants displayed a listening preference for one piece over another, it could also be taken as evidence that infants can distinguish these related but distinct pieces of complex music. Second, the findings also provided a further test of the hypothesis that infants can process music more readily when timbre is restricted. If music with a single timbre was easier for infants to process, we expected that a listening preference for one piece over the other would be more readily observed in the single timbre (piano) condition than in the multi-timbre (orchestral) condition.

It is important to note that musical complexity is relative and dependent on many factors, for example the use of musical features such as melodic salience, harmonic structure, and use of rhythmic patterns (see Price, 1986), the style of a piece, and the listener's musical experience and familiarity with a work (Hargreaves, 1984). Although no single and absolute definition of complex musical structure exists, relative differences in complexity can be established. For the present study a 20th-century musical work was selected for several reasons. First, this choice follows directly from the suggestions of Dalla Bella et al. (2001, see earlier) regarding the inadequacies of certain contemporary works for young listeners. Second, studies of infant or child preferences for 20th-century music are rare (for a discussion see Costa-Giomi \& Pennycook, 1996). Thus, a carefully selected work from this period can be accepted as being more complex relative to the musical works used in the existing infant music education literature. 


\section{Method}

\section{Sample}

Thirty 8-month-old infants (age range $=7$ months and 21 days to 8 months and 21 days) completed testing and composed the sample for Experiment 1. All infants were born at term, and were healthy and free of colds and ear infections at testing. Fifteen infants (eight boys and seven girls) were tested on the piano stimuli (single-timbre condition); 15 infants (nine boys and six girls) were tested with the orchestral stimuli (multi-timbre condition). Two additional infants were tested, but data were not included in the final sample; one did not complete testing owing to fussiness and the other did not finish the test owing to equipment failure.

\section{Stimuli}

With the considerations regarding musical complexity outlined above in mind, we selected two musical pieces (Prelude and Forlane) that form part of the work Le tombeau de Couperin by Maurice Ravel (1875-1937). The Prelude and the Forlane were purposely chosen for their contrasting styles, similar meter, and E minor tonal centers. Pieces from this work were chosen for several reasons. First, as mentioned above, this 20th-century work can be considered complex in comparison to music that is normally presented to infants such as lullabies, playsongs, and early Mozart sonatas. Under the influence of French literary Symbolism, Ravel was interested in the creation of sound colors and textures. This work favors the use of ambiguous chords and sonorities over a traditional resolution of chords. Tonal and modal harmonies grant the work some ambiguities, which makes listening to it a challenging task for the naïve listener used to listening mainly to simple and repetitive music. The pulse is not as easily followed as in a traditional lullaby. The salience of melodic contour also varies considerably within the pieces as it is often masked by instrumental range, rhythm, and harmony. Likewise, although a neoclassical work, form and melodic expectancy also vary throughout the listening. Second, compositions of this music in different timbres (piano and orchestral versions) by the same composer (Ravel) were available. Third, this work was likely to be unfamiliar to infants and their parents.

Two recordings of each piece were used: a piano version interpreted by Pascal Rogé (London Decca - CD 440 836-2) and an orchestral version interpreted by the Royal Concertgebouw Orchestra under Bernard Haitink (Philips - CD 438 745-2). Of the approximately 20 versions analyzed, these two were selected because the duration of the movements and overall piece were very similar.

For this study, eight coherent excerpts of each piece were selected in each timbre for a total of 32 excerpts: eight excerpts from the Forlane (piano), eight excerpts from the Prelude (piano), eight excerpts from the Forlane (orchestra), and eight excerpts from the Prelude (orchestra). Each musical excerpt was 20-22 seconds in duration.

\section{Procedure}

All infants were tested on the Headturn Preference Procedure (HPP), a testing procedure that measures listening preferences for one kind of auditory stimulus over another (KemlerNelson et al., 1995). Testing in the HPP (see Figure 1) was conducted in a three-sided testing booth consisting of three $120 \mathrm{~cm} \times 180 \mathrm{~cm}$ white pegboard panels. The areas between the booth and the ceiling were covered with white curtains to enclose the area and prevent the infant from getting distracted. A red light was located at the center of each side panel. Behind each one of the lights there was a hidden loudspeaker mounted to the panel. A white light was mounted on the center of the front panel. An observer was located behind the front panel and could view the baby through openings in the pegboard. Both mother 


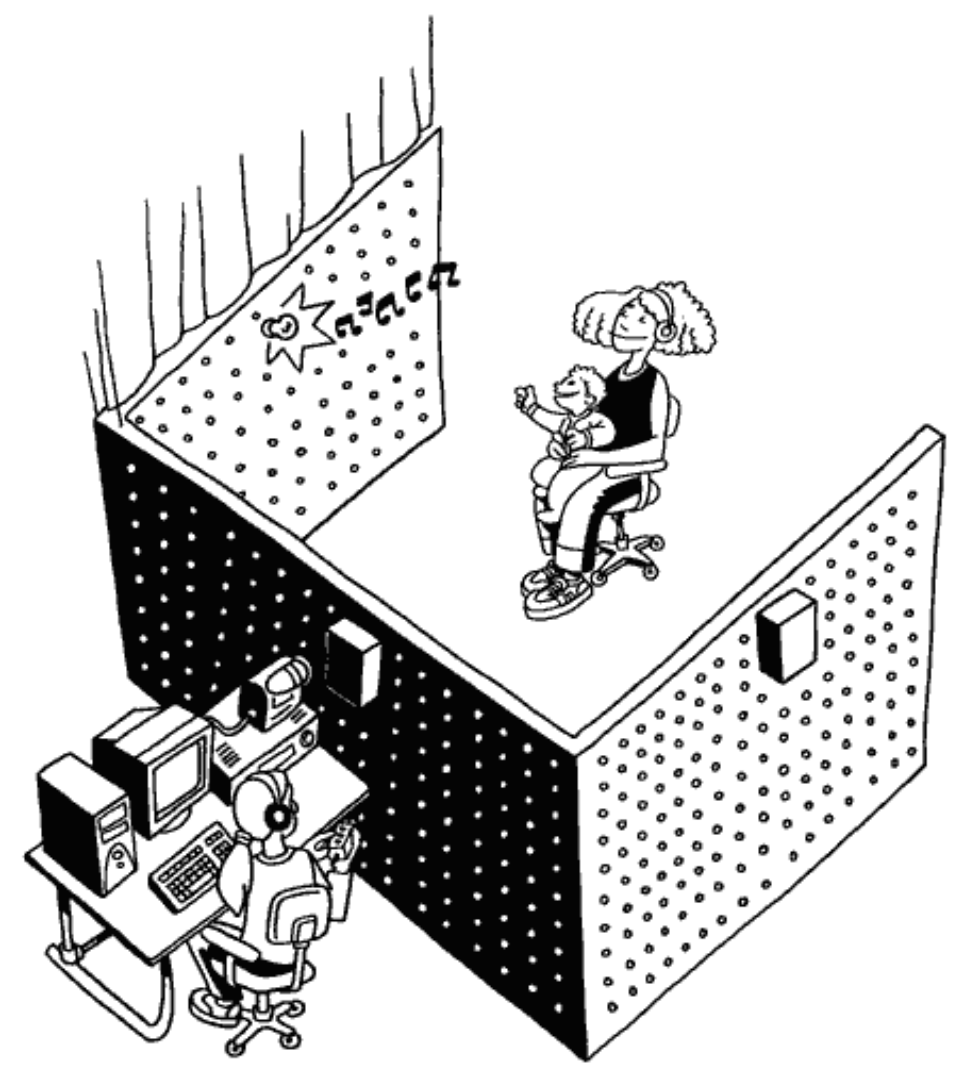

Figure 1 Illustration of the HPP procedure.

and experimenter were required to wear tight-fitting earphones delivering masking music for the duration of the entire procedure. This was done to guarantee that neither mother nor experimenter biased the infant's response.

Before the actual testing started, each infant was seated comfortably on the mother's lap in the center of the booth, facing the center light on the center panel. When the infant was facing forward at the light, the experimenter signaled the computer and started a trial. During each trial, one of the sidelights flashed urging the infant to look at it. Once the infant turned his or her head and looked at the light, the sound stimulus was played. The stimulus continued to play until the sound finished or the infant looked away. If the infant turned away from the light/sound source for at least 2 seconds, sound and light went off and the trial ended. A new trial began when the infant was once again facing forward and looking at the center light. If necessary, the experimenter used a puppet to get the infant to face forward.

Testing sessions included 16 trials: four familiarization trials and 12 test trials. Familiarization trials served the purpose of teaching the infant to turn his or her head towards the light that was flashing on either side of the panel. During each familiarization trial, the light went off once the infant turned his or her head towards it. However, during test trials the light was kept on for as long as the infant looked at it. The computer registered infant looking times for each one of the 12 trials.

Two groups of infants were tested using the HPP as described above. One group was tested with piano versions of the Forlane and Prelude pieces: a second group was tested with the orchestral versions of each piece. In each group, eight different excerpts of each 


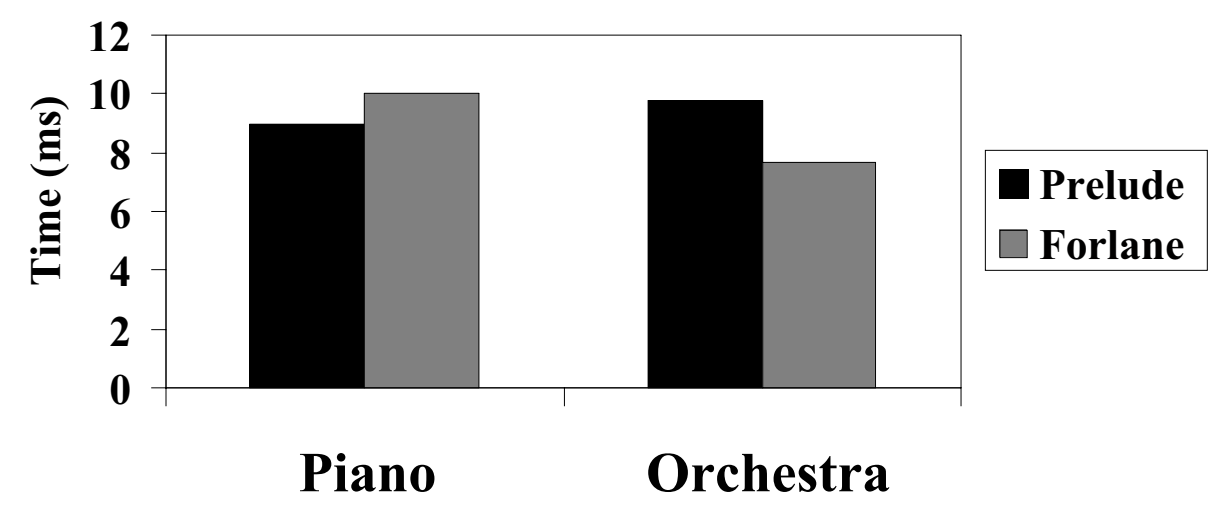

\section{Group}

Figure 2 Average mean listening time in infants presented with two pieces of music (Prelude and Forlane); results are shown for infants presented with piano music (left) and for infants presented with orchestral music (right).

piece were used. Two excerpts of each piece (Forlane and Prelude) were presented during the four familiarization trials and six different excerpts of each piece (Forlane and Prelude) were presented in the 12 test trials. For each infant, the average looking time was computed for each test trial type (Forlane and Prelude).

\section{Results}

Mean listening times across the eight excerpts of the Forlane and of the Prelude were calculated for each infant. A group average of these individual mean listening times is shown in Figure 2; infants tested in the piano condition are shown on the left and infants tested in the orchestra condition are shown on the right.

Listening time scores were analyzed in a two-way analysis of variance (ANOVA) with Timbre (Piano vs. Orchestra) as a between-subjects variable and Piece (Forlane vs. Prelude) as a within-subjects variable. Neither the main effect of Timbre $(F(1,28)=0.260, p>.05)$ nor the main effect of Piece $(F(1,28)=1.332, p>.05)$ were statistically significant. However, the interaction between Timbre and Piece was significant $(F(1,28)=5.198, p<.05)$.

Simple effect analyses were conducted to examine preference for Piece (Prelude vs. Forlane) within each timbre condition. Infants tested with the piano stimuli showed no listening time differences for the Prelude and the Forlane pieces $(t(14)=.737, p=.370$, two-tailed). Infants tested with the orchestral stimuli showed significantly longer listening time to the Prelude compared to the Forlane piece $(t(14)=-2.662, p=.019$, two-tailed); eight of the 15 babies tested showed this pattern. Simple effects of timbre between subjects were also analyzed. As shown in Figure 2, average listening times were longer for the piano timbre compared to the orchestral timbre. This difference was not significantly different across infants for the Prelude $(t(28)=.555, p=.583)$, but it was marginally significant for the Forlane piece $(t(28)=1.97, p=.059)$.

\section{Discussion}

The results show that infants displayed a reliable preference for the Prelude over the Forlane when played by an orchestra, but displayed no listening preference across the two pieces when played on the piano. From this we can conclude that infants could discriminate these 


\section{INTERNATIONAL JOURNAL OF MUSIC EDUCATION 24(1)}

contrasting musical pieces within the multi-timbre composition. However, the specific feature (or features) that supported infant preference pattern in this orchestral music is not known. The lack of preference for either piece in the piano condition is inconclusive with respect to discrimination. Infants may have been able to distinguish the Forlane and Prelude pieces in the piano timbre, but did not prefer to listen to one more than the other. Overall, the findings showed that piano pieces attracted more infant attention compared to the orchestral pieces and they provide an initial no-preference baseline, making these stimuli an appropriate choice for conducting a memory study within a preference paradigm.

\section{Experiment 2}

Experiment 2 was designed to assess infant long-term memory for complex music. As mentioned earlier, several studies have demonstrated infant long-term memory for spoken words. As well, Saffran et al. (2000) provide evidence that infants can form a long-term memory representation for a musical piece over a 2-week delay. In this study we utilized the same basic design as these previous studies. We repeatedly exposed a group of infants to a piece of music for approximately 10 days and then tested them to determine whether they display a preference for the piece heard during the exposure period. However, we used music considered to be more complex compared to music used in the Saffran et al. (2000) and Trainor et al. (2004) studies, that is, the Prelude and Forlane pieces from Experiment 1. Infants listened to one of the pieces (Forlane or Prelude) during the exposure period and then completed a listening preference test (using both pieces) after a 2-week delay. We predicted that infants would listen longer to the piece heard during the exposure period than to an unfamiliar piece from the same musical work, showing that they are able to form a representation in long-term memory for the specific piece they had previously heard. This outcome would indicate that infants possess abilities that allow them to process and retain some aspects of complex music. The piano versions of the two Ravel pieces used in Experiment 1 were used for this experiment. (Recall that in Experiment 1 infants without any previous exposure to this music had no initial listening preference when presented with the piano versions of the Forlane and Prelude.)

\section{Method}

\section{Sample}

Thirty infants ( 15 boys and 15 girls) completed testing in Experiment 2 (age range at test $=$ 8 months to 8 months and 21 days; mean age $=8$ months and 12 days). An additional 22 infants were recruited into the study but were not included in the final sample for the following reasons: late parental report of developmental disabilities $(n=1)$, fussiness during testing $(n=1)$, parental interference during testing $(n=1)$, colds or ear infections at the time of testing $(n=2)$, failure to complete the exposure protocol $(n=10)$, deviation from exposure protocol $(n=7)$.

\section{Stimuli}

The stimuli were the same as for Experiment 1.

\section{Procedure}

Each infant was randomly assigned to one of two exposure conditions: Prelude or Forlane. Each infant-parent dyad completed three experimental phases. Phase 1, the Exposure phase, lasted for 10 consecutive days. The researcher scheduled a home visit with each 
participating family. During the visit, the study was explained to parents who were then asked to sign consent forms. Parents and caretakers were interviewed on musical behaviors of their families (for the interview data refer to llari, 2005) and received a CD that contained the designated piece, either the Prelude or the Forlane in piano timbre. In order to guarantee optimal listening conditions for the infant, parents and caretakers were instructed to listen to the assigned musical piece three times a day, when the infant was in a quiet and alert state and the home environment was calm and peaceful. Parents and caretakers were also asked to fill out a specially designed music listening diary providing the date, time, and infant mood during each listening session. The researcher followed up on each family by phoning once during the 10-day listening period to ensure that the procedures were being followed properly.

Phase 2, the Retention phase, lasted for 14 consecutive days. As soon as the Exposure phase ended (i.e. as soon as the infant heard the piece three times a day for 10 consecutive days), the researcher scheduled a CD pick-up date. CDs were collected to ensure that infants did not listen to the familiar piece of music during the 14-day retention phase. During this phase, families were free to listen to any music they wanted except the Ravel pieces being used in the study. A laboratory visit was scheduled for the first day after the 14-day Retention phase.

Phase 3 was the Test phase in which infants were tested in the university laboratory on their preference for the Forlane and Prelude pieces played on the piano using HPP as described in Experiment 1. For half of the infants, the Forlane test trials were familiar and the Prelude trials were unfamiliar; for the other half the Prelude trials were familiar and the Forlane trials were unfamiliar.

\section{Results and discussion}

Mean listening time scores were computed for each baby for the familiar and for the unfamiliar musical piece. The average listening time scores for the familiar and unfamiliar music are shown in Figure 3.

Results of a one-tailed paired samples t-test confirmed our prediction that infants would listen longer to the familiar piece $(t(29)=1.939, p<.05)$. Eighteen out of 30 babies listened longer to the piece heard during the exposure period.

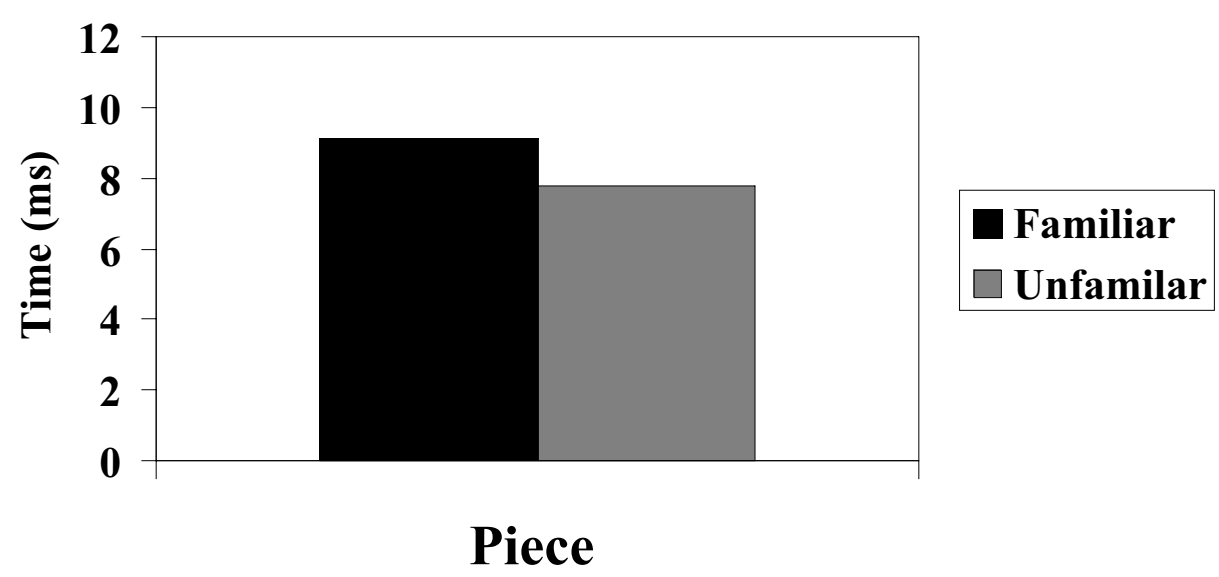

Figure 3 Average mean listening time in infants presented with a familiar (heard repeatedly over a 10-day exposure period) and an unfamiliar (no exposure) musical piece in a listening preference test conducted 2 weeks after the exposure period. 


\section{INTERNATIONAL JOURNAL OF MUSIC EDUCATION 24(1)}

Results found here were clear and conclusive. Consistent with our predictions, infants listened significantly longer to the familiar piece. This finding indicates that 8-month old infants have the ability to retrieve the complex auditory information present in Ravel's Prelude and Forlane that was previously encoded and stored in memory. The exact information that infants encoded during exposure and accessed during the familiarity preference test is not known. Yet, the present findings suggest that young infants can retain in long-term memory music that is a bit more complex than the traditional repertoire found in early childhood music education resources (e.g. nursery rhymes, lullabies, and playsongs).

\section{General discussion}

Contrary to many beliefs, infants' music processing abilities are not limited to simple music. Young infants are responsive to complex pieces of music and display some listening preferences when they are presented samples of complex music for the first time. Findings from this study suggest that timbre cues play an important role in infant perception, preference, and discrimination of complex pieces of music, including in a first listening. For the music used in the present study, it seems that the discrimination of two contrasting complex pieces of music was facilitated when the music was performed in multiple and not single timbres. This finding raises the question of whether a musical piece played in multiple timbres is actually easier for a naive listener to attend to than the same piece played in a single timbre. Is there a correlation between timbre and the ability of naïve listeners to discriminate between elements of musical form (i.e. motifs, phrases, melodies, accompaniments) in a complex piece of music? This is an important question that we pitch for future research to answer.

Nevertheless, data from our study suggests that even a fairly complex piece of music can be encoded and memorized by a naïve listener, given a certain amount of repetition. At 8months, infants are capable of encoding and storing complex auditory information found within a piece of music, for at least 2 weeks. Although the exact features that were encoded remain unknown, it is quite clear that some aspect of the music, which allowed for recognition to occur, was stored in the mind of our participating infants. Future studies could address this issue and pinpoint exactly what features account for infant long-term memory for music. However, due to the lack of studies in the area, caution in the generalization of these results is needed, notably in what concerns how long these musical memories will last. To this date, the longer-term effects of infant musical memories remain unknown. Therefore, answers regarding the permanence of early musical experiences will only be available through longitudinal studies.

Overall, this study supports a view of infants as sophisticated listeners. Attuned to the sounds that surround them, pre-verbal infants are what Small (1998) called 'psychological and intellectual sponges', who pick up and encode much information from their environment including the acoustical one. For both speech and music, it appears that infants are already equipped with some remarkable auditory learning capacities, which are in place during the first year of life. Yet, if an infant could choose, would he or she prefer to listen to a simple or to a complex piece of music? This is a question that the present investigation did not address and that we are currently pursuing in our laboratory. Despite their choice, it is evident from this study that pre-verbal infants are ready to handle music that is more complex than traditional lullabies and playsongs in many ways. However, we do not mean to suggest that parents and caretakers should play complex music for their babies instead of simple music, nor that complex music is the most appropriate type of music for babies. 
Rather, we suggest that parents and caretakers do not need to limit their infants to simple or stereotyped 'baby music' if they like classical or other genres. They should select music that they deem appropriate, be it simple or complex, always attuned to their child's reaction and to loudness levels. By choosing repertoire guided by their own likes and their infants' reactions, parents can engage in meaningful and enjoyable musical activities with their infants (for a discussion see Custodero, 2002). Such activities could be beneficial for both infants and mothers alike. Further research on the listening preferences and effects of music experience during infancy are also needed to better understand how infants perceive and process complex music. Such works will add much-needed information to the body of knowledge on infant music cognition and are likely to make a contribution towards the enhancement of the musical lives of infants and their caretakers.

\section{References}

Abrams, R. M., Griffiths, S. K., Huang, X., Sain, J., Langford, G., \& Gerhardt, K. J. (1998). Fetal music perception: The role of sound transmission. Music Perception, 15, 307-317.

Balakrishnan, S. (1980). Folk music of Tamilnad. In G. Kuppuswamy \& M. Hariharan (Eds.), Indian music: A perspective (pp. 156-163). Delhi: Sundeep Prakashan.

Berk, L. E. (1999). Infants and children: Prenatal through middle childhood. Boston, MA: Allyn \& Bacon.

Bertsch, C. (2000). Music for babies, or, how I'm reconciling fatherhood with my record collection. Bad Subjects, 47, 1-5.

Blacking, J. (1967). Venda children's songs: An ethnomusicological analysis. Chicago: Chicago University Press.

Clifton, R. K. (2001). Lessons from infants: 1960-2000. Infancy, 2, 285-309.

Costa-Giomi, E., \& Pennycook, B. (1996). Third-grade children's preferences for Canadian electroacoustic music. Canadian Journal of Research in Music Education, 37, 23-26.

Custodero, L. A. (2002). The musical lives of young children: Inviting, seeking and initiating. Journal of Zero to Three, 23, 4-9.

Custodero, L. A., Britto, P., \& Brooks-Gunn, J. (2003). Musical lives: A collective portrait of American parents and their young children. Applied Developmental Psychology, 24, 553-572.

Custodero, L., Britto, P., \& Xin, T. (2002). From Mozart to Motown, lullabies and love songs: A preliminary report on the Parents' Use of Music with Infants Survey (PUMIS). Journal of Zero to Three, 23, 41-46.

Dalla Bella, S., Peretz, I., Roussaeu, L., \& Gosselin, N. (2001). A developmental study of the affective value of tempo and mode in music. Cognition, 80, B1-B10.

DeCasper, A. J., \& Fifer, W. (1980). Of human bonding: Newborns prefer their mothers' voices. Science, 208, 1174-1176.

Demany, L., McKenzie, B., \& Vurpillot, E. (1977). Rhythm perception in early infancy. Nature, 266, 718-719.

Ferland, M. B., \& Mendelson, M. J. (1989). Infants' categorization of melodic contour. Infant Behavior and Development, 12, 341-355.

Fernald, A. (1989). Intonation and communicative intent in mothers' speech to infants: Is the melody the message? Child Development, 60, 1497-1510.

Hargreaves, D. J. (1984). The effects of repetition on liking for music. Journal of Research in Music Education, 32, 35-47.

Houston, D. M., \& Jusczyk, P. W. (2003). Infants' long-term memory for the sound patterns of words and voices, Journal of Experimental Psychology: Human Perception and Performance, 29, 1143-1154.

Hunter, M. A., \& Ames, E. W. (1988). A multifactor model of infant preferences for novel and familiar stimuli. Advances in Infancy Research, 5, 69-95.

Ilari, B. (2002). Music perception and cognition in the first year of life. Early Child Development and Care, $172,311-322$.

Ilari, B. (2005). On musical parenting of young children: Musical beliefs and behaviors of mothers and infants. Early Child Development and Care, 175(7\&8), 647-660.

Ilari, B., \& Johnson-Green, E. (2002). Musical resources for children. Journal of Zero to Three, 23, 49-52.

llari, B., \& Majlis, P. (2002). Children's songs around the world: An interview with Francis Corpataux. Music Education International, 1, 3-12.

Johnson-Green, E., \& Custodero, L. (2002). The toddler top 40: Musical preferences of babies, toddlers and their parents. Journal of Zero to Three, 23, 47-48. 


\section{INTERNATIONAL JOURNAL OF MUSIC EDUCATION 24(1)}

Jusczyk, P. W., \& Hohne, E. A. (1997). Infants' memory for spoken words. Science, 277, 1984-1986.

Kemler-Nelson, D. G., Jusczyk, P. W., Mandel, D. R., Myers, J., Turk, A., \& Gerken, L. (1995). The headturn preference procedure for testing auditory perception. Infant Behavior and Development, 18, 111-116.

Krumhansl, C. L., \& Jusczyk, P. W. (1990). Infants' perception of phrase structure in music. Psychological Science, 1, 70-73.

Lynch, M. P., \& Eilers, R. E. (1992). A study of perceptual development for musical tuning. Perception and Psychophysics, 52, 599-608.

Melen, M., \& Wachsmann, J. (2001). Categorization of musical motifs in infancy. Music Perception, 18, 325-346.

Michel, P. (1973). The optimum development of musical abilities in the first years of life. Psychology of Music, 1, 14-20.

Pick, A. D., Gross, D., Heinrich, K., Love, M., \& Palmer, C. (1994). Development of the perception of the unity of musical events. Cognitive Development, 9, 355-375.

Price, H. E. (1986). A proposed glossary for use in affective response literature in music. Journal of Research in Music Education, 34, 151-159.

Rock, A. M. L., Trainor, L. J., \& Addison, T. (1998). Distinctive messages in infant-directed lullabies and playsongs. Developmental Psychology, 35, 527-534.

Saffran, J. W., Loman, M. M., \& Robertson, R. R. W. (2000). Infant memory for musical experiences. Cognition, 77, B15-B23.

Schellenberg, E. G., \& Trehub, S. E. (1996). Natural music intervals: Evidence from infant listeners. Psychological Science, 7, 292-296.

Schoenstein, R. (2002). Toilet trained for Yale: Adventures in 21st century parenting. Cambridge, MA: Perseus Press.

Small, M. F. (1998). Our babies, ourselves: How biology and culture shape the way we parent. Toronto: Random House.

Spence, M. J. (1996). Young infants' long-term memory: Evidence for changes in preference as a function of delay, Developmental Psychobiology, 29, 695.

Trainor, L. J. (1996). Infant preferences for infant-directed versus non-infant directed playsongs and lullabies. Infant Behavior and Development, 19, 83-92.

Trainor, L. J., Austin, C. M., \& Desjardins, R. N. (2000). Is infant-directed speech prosody a result of the vocal expression of emotion? Psychological Science, 11, 188-195.

Trainor, L. J., \& Heinmiller, B. M. (1998). The development of evaluative responses to music: Infants prefer to listen to consonance over dissonance. Infant Behavior and Development, 21, 77-88.

Trainor, L. J., \& Trehub, S. E. (1990). Rules for listening in infancy: In J. T. Enns (Ed.), The development of attention: Research and theory (pp. 87-119). North Holland: Elsevier Science Publishers.

Trainor, L. J., Wu, L., \& Tsang, C. D. (2004). Long-term memory for music: Infants remember tempo and timbre. Developmental Science, 7, 289-296.

Trainor, L. J., \& Zacharias, C. A. (1998). Infants prefer higher-pitched singing. Infant Behavior and Development, 21, 799-806.

Trehub, S. E., Bull, D., \& Thorpe, L. A. (1984). Infants' perception of melodies: The role of melodic contour. Child Development, 21, 821-830.

Trehub, S. E., \& Thorpe, L. A. (1989). Infants' perception of rhythm: Categorization of auditory sequences by temporal structure. Canadian Journal of Psychology, 43, 217-229.

Trehub, S. E., \& Trainor, L. J. (1993). Listening strategies in infancy: The roots of music and language development. In S. McAdams \& E. Bigand (Eds.), Thinking in sound: The cognitive psychology of human audition (pp. 278-320). Oxford: Clarendon Press.

Trehub, S. E., Unyk, A. M., Kamenetsky, S. B., Hill, D. S., Trainor, L. J., Henderson, M., et al. (1997). Mothers' and fathers' singing to infants. Developmental Psychology, 33, 500-507.

Werker, J. F., Shi, R., Desjardins, R., Pegg, J. E., Polka, L., \& Patterson, M. (1998). Three methods for testing infant speech perception. In A. Slater (Ed.), Perceptual development: Visual, auditory, and speech perception in infancy (pp. 389-420). Hove: Psychology Press.

West, M. (2000). Music therapy in antiquity. In P. Horden (Ed.), Music as medicine (pp. 51-68). Aldershot: Ashgate.

Wilkin, P. (1991). Antenatal and postnatal responses to music and sound stimuli - a clinical report. Canadian Music Educator - Research Edition, 33, 223-232.

Wilkin, P. (1995). A comparison of fetal and newborn responses to music and sound stimuli with and without daily exposure to a specific piece of music. Bulletin of the Council for Research in Music Education, 27, 163-169.

Woodward, S. C., Guidozzi, F., Hofmeyr, G. J., Jong, P., Anthony, J., \& Woods, D. (1992). Discoveries in the fetal and neonatal worlds of music. International Society for Music Education Yearbook, 58-66. 
Zentner, M. R., \& Kagan, J. (1998). Infants' perception of consonance and dissonance in music. Infant Behavior and Development, 21, 483-492.

Beatriz llari is an Associate Professor of Music Education at the Federal University of Paraná in Curitiba, Brazil, where she runs an early childhood music education program. Her research concerns music perception and cognition in infancy, and has been published in different parts of the world. She is currently running a study on Brazilian children's musical development - north to south. A former secretary for the Brazilian Association for Music Education (ABEM), Dr llari is now working towards the creation of a music cognition association in Brazil.

Address: Federal University of Paraná (UFPR), Deartes, Rua Coronel Dulcidio 638 Batel, 80420-170, Brazil. [email: beatrizilari@yahoo.ca]

Linda Polka is an Associate Professor of Psychology (developmental speech perception) in the School of Communication Sciences and Disorders, McGill University, Canada. Her research interests center on the development of speech perception and production with a focus on understanding how language experience shapes perception of segmental and prosodic structure and word-learning skills in infancy. Her current research explores the emergence of these skills in infants being raised in monolingual and bilingual families and in infants with and without a history of middle ear infections. Her recent publications include articles for the journals Infancy, Cognition, and Speech Communication, and she has contributed a chapter (with S. Rvachew and K. Mattock) to the forthcoming book Handbook of Child Language (Eds. E. Hoff and M. Shatz, Oxford).

Address: Infant Speech Perception Lab, McGill University, 1266 Pine Ave West, Montreal QC H3G 1A8, Canada. [email: linda.polka@mcgill.ca]

\section{Abstracts \\ Reconnaître la musique dès la petite enfance: La préférence des enfants en bas âge pour la musique de Ravel et leur mémoire à long terme}

Des préférences d'écoute pour deux morceaux, 'Prélude' et 'Forlane' (Le tombeau de Couperin par Maurice Ravel, 1875-1937), ont été évaluées dans deux expériences entreprises avec des bébés ayant 8 mois d'âge, en utilisant le processus 'Headturn Préférence' (direction dont le bébé tourne la tête). L'expérience \#1 a prouvé que les enfants en bas âge, qui n'ont jamais entendu les morceaux, peuvent faire une distinction précise entre les pièces 'Prélude' et 'Forlane' quand ces dernières sont exécutées avec des timbres multiples (c.-à-d., orchestre) mais pas quand ils sont exécutés avec un seul timbre (c.-à-d., de piano). Au cours de l'expérience \#2, certains bébés ont été exposés à plusieurs reprises, sur une période de 10 jours, à un des deux morceaux joués au piano. En concurrence avec des études précédents, les résultats suggèrent que les bébés peuvent identifier le morceau familier, même après une pause de 2 semaines. Des implications pour l'importance de l'éducation musicale des jeunes enfants se trouvent à la fin de l'article.

\section{Musikalische Wahrnehmung in der frühen Kindheit: Präferenzen und Langzeitgedächtnis in Bezug auf Musik von Ravel bei Säuglingen}

In zwei Experimenten mit 8-monatigen Säuglingen wurde die Hörpräferenz für zwei Stücke, das Prélude und die Forlane aus Le Tombeau de Couperin von Maurice Ravel mit Hilfe des 


\section{INTERNATIONAL JOURNAL OF MUSIC EDUCATION 24(1)}

Head-turn Paradigmas untersucht. Experiment 1 zeigte, dass Kinder, die diese Stücke nie gehört hatten, deutlich zwischen dem Prélude und der Forlane unterschieden, wenn sie in gemischten Klangfarben (z.B. Orchester) statt in einer einzigen Instrumentalversion (z.B. Klavier) vorgespielt wurden. Im 2. Experiment wurde den Kindern während der Dauer von 10 Tagen eines der Klavierstücke wiederholt vorgespielt. Übereinstimmend mit früheren Studien deuten die Ergebnisse darauf hin, dass Babys das bekannte Stück nach zwei Wochen wiedererkennen können. Am Ende der Beitrags werden Folgerungen für die musikalische Früherziehung gezogen.

\section{Cognición musical en la temprana infancia: Las preferencias y la memoria a largo plazo de los bebés para Ravel}

Dos experimentos evaluaron la preferencia de audición de bebés de 8 meses de edad con dos obras de Maurice Ravel (1875-1937), Prelude y Forlane de Le tombeau de Couperin, utilizando el Procedimiento de preferencia por rotación de cabeza (Headturn Preference Procedure). El Experimento 1 mostró que los bebés que nunca antes habían escuchado las obras, podían claramente distinguir entre el Preludio y Forlane cuando esta última era ejecutada por timbres múltiples (es decir, la orquesta) pero no con un timbre simple (es decir, el piano). En el Experimento 2, los bebés fueron expuestos durante diez días a la audición repetida de una de las dos piezas.

Coincidentemente con estudios previos, los resultados sugieren que después de una semana de suspendido el tratamiento, los bebés pueden reconocer la pieza familiar. Las implicaciones para la educación musical en la temprana infancia se describen al final del trabajo. 